кУЛЬтУРОЛОГИя

УДК: 902/904, 903.33, 903.39, 551.583.2.

ИСТОРИЯ ОСВОЕНИЯ ДРЕВНЕЙ ДЕЛЬТЫ РЕКИ ИЛИ С ІІ В. ДО Н. Э. ПО ХІІІ В. Н.Э. И ЗНАЧЕНИЕ ВЕЛИКОГО ШЕЛКОВОГО ПУТИ В ЕЁ РАЗВИТИИ.

DOI: $10.31618 /$ ESU.2413-9335.2019.8.68.462

Стасив Игорь Васильевич

Геолог-краевед

Украина, пгт. Новая Боровая

\title{
THE HISTORY OF THE MASTERING OF THE ANCIENT ILI RIVER DELTA FROM THE II CENTURY BC TO THE XIII CENTURY AD AND THE SIGNIFICANCE OF THE GREAT SILK ROAD IN ITS DEVELOPMENT.
}

\author{
Stasiv Igor Vasilyevich \\ Local Geologist \\ Ukraine, town of Novaya Borova
}

\begin{abstract}
АННОТАЦИЯ
В статье автором дано краткое описание озера Балхаш и древней долины реки Или. Описана история заселения древней дельты реки Или племенами саков, усуней, тюрков, огузов, занимающихся полукочевым скотоводством и поливным земледелием, а также охотой, рыбалкой и добычей соли. Приведены описания выявленных сакско-усуньских поселений-землянок, известных городищ-крепостей и выявленных неизвестных городищ-крепостей, расположенных вдоль следования караванов ответвления Великого Шелкового пути и его значение на развитие древней долины реки Или. Изложены причины приведшие к поднятию уровня воды в Балхаш-Алакольской впадине в XIII веке и затоплению древней дельты реки Или, разрушению городищ и земледельческих поселений, упадку уникальной системы орошения и земледелия, уходу проживающего населения в другие обитаемые места.

\section{ABSTRACT}

In the article, the author gives a brief description of Lake Balkhash and the ancient valley of the Ili River. The history of the settlement of the ancient delta of the Ili River by the tribes of Saks, Usuns, Turks, Oguzes, engaged in semi-nomadic cattle breeding and irrigated agriculture, as well as hunting, fishing and salt mining is described. Descriptions of revealed Sax-Usun settlements-dugouts, known fortified settlements and identified unknown fortified settlements located along the caravans of the Great Silk Road branch and its significance for the development of the ancient Ili river valley are given. The reasons that led to a rise in the water level in the BalkhashAlakol depression in the 13th century and the flooding of the ancient Ili River delta, the destruction of ancient settlements and agricultural settlements, the decline of the unique irrigation and farming system, and the departure of the living population to other inhabited places are described.

Ключевые слова: Озеро Балхаш; древняя дельта реки Или; кочевое, полукочевое и оседлое проживание саков, усуней, тюрков, карлуков и огузов; земледелие и скотоводство; ответвление Великого Шелкового пути; городища и поселения-торткули; глобальные климатические процессы XII- XIII вв.

Keywords: Lake Balkhash; ancient delta of the Ili River; nomadic, semi-nomadic and sedentary residence of Saks, Usuns, Turks, Karluks and Oguzes; agriculture and cattle breeding; branch of the Great Silk Road; hillforts and settlements-tortkuli; global climatic processes of the XII-XIII centuries.
\end{abstract}

Введение. До XII веках территория Южного Прибалхашья представляла собой большую песчаную полупустыню, расчленённую крупными долинами рек Или, Каратал, Аксу, Лепсы, которые впадали в озеро Балхаш, занимающее северную часть Балхаш-Алакольской впадины. Очевидно в те времена, озеро Балхаш имело иную форму, и разделялось в районе современного полуострова Сарыесик, на два самостоятельных водоёма, с различными химическими характеристиками воды. Западная его часть была пресноводной и мелководной, а восточная совместно с озерами Сасыколь и Алаколь имела солоноватую воду, большие размеры и глубины, где в центре его находился остров Коишор. Пресноводная западная часть современного озера Балхаш, восточными огузами, проживавшими здесь с серелины VIII по X вв. н.э., именовалась, как озеро «Горгуз» [1], а солоноватая восточная часть водоема, местными карлуками, как озеро «Тенгиз».

Это подтверждается тем фактом, что в период c V-IV вв. до н.э. и по IV-VI вв. н.э., в районах Средней Азии отмечались климатические катаклизмы, вызванные глобальными потеплениями и похолоданиями. Данные климатические изменения вызывали периодические колебания уровня воды в озерах Балхаш-Алакольской впадины, что приводило к ее понижению (высыханию) или поднятию до 30 и более метров, объединяясь в единый водоем. Также 
они еще оказывали воздействие на стоки рек, впадающие в эти озера, которые повременно увеличивали приток воды или понижали его, образуя при этом разнообразные дельты с многочисленными протоками-руслами. Наиболее крупными в то время были реки Токрау и Или, которые сыграли главную роль в дальнейшем образовании современного озера Балхаш.

В целом реки Токрау и Или относится к транзитному типу рек. Такие реки, вытекающие с горных районов, протекая в дальнейшем на сотни километров по равнинным пустыням, не получали больше дополнительных притоков воды со стороны, но, тем не менее, несли в своих водах много взвеси в виде ила, глины и тонкозернистого песка. По пути следования основного русла, эти частицы оседали на дно, постепенно приподнимая его выше окружающей равнины, что приводило к изменению формы русла, образуя потом, своеобразную дельту треугольной формы, с многочисленными извивающимися рукавами и ответвлениями мелких проток, уменьшая тем самым сток воды от основного русла и увеличивая площадь дельты.

Так случилось, что в результате этих частых трансгрессий и регрессий вод в озере Балхаш, происходивших с V вв. до н.э. по VI вв. н.э., наносная деятельность этих рек, стала слишком высокой, что привело к расширению и удлинению дельт рек Токрау и Или, которые в конце VI века н.э. воссоединились между собой в единый массивперешеек. Это привело к расчленению озера Балхаш на две части, где в его восточной части преобладали солоноватые воды, а в западной пресные, так как они постоянно пополнялись сточными водами реки Или, дающими до 80 \% всего притока воды в западную часть разделенного водоема [2].

Основную же роль в этом разделении, сыграла река Токрау, бравшая свое начало в горах Центрального Казахстана. Она на то время, была очень полноводной и несущей с собой большое количество твердых взвешенных осадков в виде ила, глины и разнозернистого песка. При впадении в озеро Балхаш, река Токрау создала большую дельту длинной до 50-60 км и шириной до 40 км с многочисленными рукавами, которая постоянно увеличивалась в сторону древней дельты реки Или, пока не воссоединилась с ней. Остатки дельты с рукавами на сегодняшний день хорошо сохранились в северной и северо-восточной части полуострова Сарыесики и хорошо просматриваются на спутниковых картах. В дальнейшем, образованный перешеек, служил переходом для древних племен с территорий Центрального Казахстана в район древней дельты реки Или, а также прохождения караванов Великого Шелкового пути.

Древняя дельта реки Или в те времена, была одним из богатейших природных комплексов Южного Прибалхашья и занимала огромное пространство, длинной около 220 км и шириной до 180 км. Свое начало она брала севернее поселка
Баканас, где основная ее восточная часть проходила через пустыню Сарыесик-Атырау разделяясь на серию рукавов, именуемые сегодня баканасами (сухими руслами) - Нарын, ОртаБаканас, Кара-Баканас, Шет-Баканас и Ортасу. Это послужило к развитию в древней долине реки Или животноводства и земледелия

Актуальность данной статьи заключается в том, что в настоящее время имеется много общей разнообразной информации приведенной в научных журналах, книгах и интернете о освоении древней дельты реки Или. Настоящая работа основана на материалах известных и выявленных автором новых неизвестных археологических памятников животноводческих и оседлоземледельческих культур в пределах древней дельты реки Или, относяхщихся к периоду с II тыс. до н.э. по XIII в. н.э.. Детально описаны маршруты движения караванов и их стоянок, одного из ответвления Великого Шелкового пути, проходившего через древнюю долину реки Или и причинах прекращения их деятельности, а так же кочевого скотоводства и поливного земледелия.

Цель данной статьи состоит в изучении процессов становления и развития скотоводческой и оседло-земледельческой культур на территории древней дельты реки Или, значения на их формирование одного из ответвлений Великого Шелкового пути и причинах прекращения их деятельности.

Научная новизна данной статьи заключается в том, что в ней обобщены известные и выявленные автором археологические свидетельства, отражающие становления животноводческой и оседло-земледельческой культур в пределах древней реки Или и прилегающей к ней территориях. Детально описаны выявленые новые неизвестные сакско-усуньские земляночные поселения и тюрко-огузкие городища, а так же маршруты движения торговых караванов одного из ответлений Векикого Шелкового пути с местами их временных стоянок. По спутниковым снимкам на южном берегу озера Балхаш обнаружено неизвестное городище, которое могло быть прототипом древнему городу-крепости Горгуз. Описаны причины ухода проживающих племен с территории древней реки Или и прекращения движения торговых караванов. Приведенные материалы, позволят по-новому взглянуть на процесс становления древней долины реки Или и роль ответвления Великого Шелкового пути на её развитие.

В 1984-87 г.г. мною в Южном Прибалхашье, южнее полуострова Сарыесик в районе старых сухих русел Шет-Баканас, Ортасу реки Или, городища Карамерген и песков пустыни СарыесикАтырау, проводились глубинные геологосъемочные работы масштаба 1:50 000 по оценке крупной геофизической аномалии похожей по своим характеристикам на аномалию рудного поля известного медно-молибденового месторождения Коунрад. Так, что эти места Южного Прибалхашья я хорошо знаю, и у меня исходя, из увиденного в 
процессе проведения геологических работ, сложились свои представления, об этих уникальных пустынных местах, условиях проживания и деятельности местного населения в те времена, а также значение Великого Шелкового пути в их развитии.

В районе современного полуострова Сарыесик в конце VI века н.э. в процессе воссоединения с дельтой реки Токрау, восточная часть древней дельты реки Или разделилась на две части, где рукав Шет-Баканас впадал в восточную часть озера Балхаш, а Ортасу, Нарын с Орта-Баканасом и многочисленными мелкими рукавами в западную, сильно опресняя её. В целом данная часть дельты характеризовалась хорошо развитыми плавнями с зарослями камыша и другой прибрежной растительности, наземного животного и рыбного мира. По берегам рукавов и между ними находились массивы зарослей саксаула и туранговых рощ, в которых водились фазаны, кабаны, сайгаки, корсаки, волки, камышовые коты и тигры, одичавшие лошади. В северо-восточной части дельты, ближе к прибрежной части современного озера Балхаш, широкое развитие получили небольшие остаточные соленые озера с соленостью воды до рапы и солонцы, с пластами прозрачной каменной соли. В периоды весенних паводков и поднятий уровня воды в озере, они подпитывали солью его восточную часть, повышая тем самым солоноватость вод. Южнее от прибрежной солонцовой зоны, древняя дельта реки Или с поверхности была покрыта плодородным илом на глубину до 30 и более сантиметров, который в результате регулярных затоплений постоянно поновлялся и служил прекрасным удобрением для выращивания сельхозкультур. Поэтому земледелие здесь было очень продуктивным, но из-за происходивших периодических наводнений и засух, приводивших к избытку или нехватки воды, возникала потребность в проведении ирригационных работ - по осушению, орошению, возведению дамб, запруд и подводящих каналов, служивших для сбора и направления воды в нужные места. Это и послужило древней дельте р. Или еще до н.э., стать центром земледелия, кочевого и полукочевого скотоводства, охоты, рыболовства для многих проживающих здесь кочевых племен.

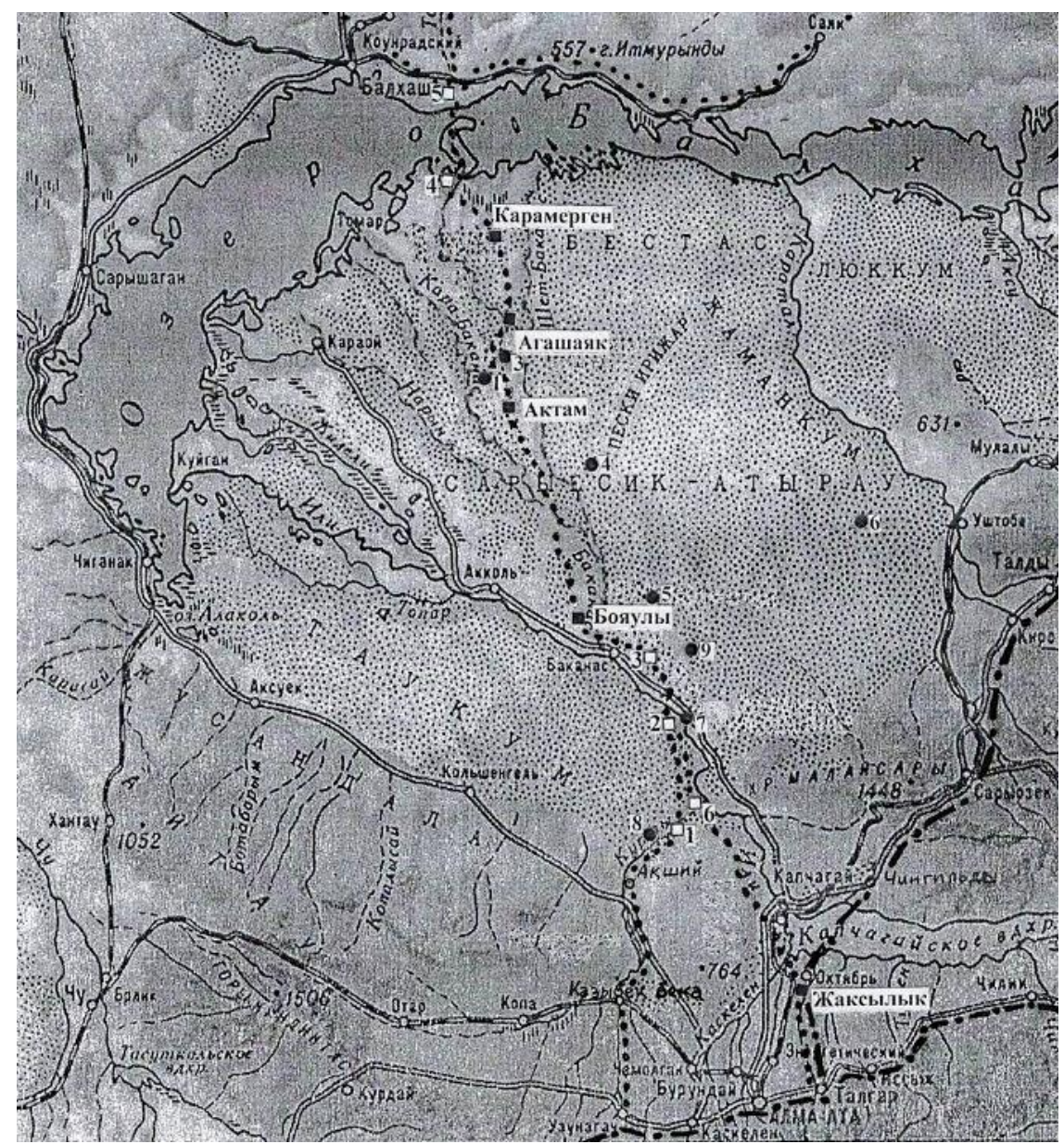

Рис. 1. Карта древней дельты реки Или с поселениями, городчщами и маршрутами движения караванов Великого Шелкового пути.

- $\quad$ неизвестные поселения из землянок сакско-усуньского времени;

$\square \quad$ неизвестные поселения и городища тюрко-огузского времени;

口 н неизвестные поселения и городища тюрко-огузского времс

- - основные трассы движения караванов Великого Шелковаго пути;

$\bullet \bullet \bullet$ ответвления маршрутов караванов через древнюю долину реки Или. 
C середины 2-го тысячелетия до н.э., на территории Казахстана происходили природноклиматические изменения в сторону большой сухости, что привело значительную часть степных племен проживающих в Семиречье, переходить к оседлому проживанию в поймах крупных рек и развитию комплексного скотоводческоземледельческого хозяйства.

Одними из первых, кто начал освоение пустынных и плодородных земель древней дельты реки Или в те времена, были сакские племена [3]. Саки в основном занимались кочевым и полукочевым скотоводством, в котором главное значение имело коневодство и овцеводство, частично выращивали верблюдов и крупный рогатый скот, питаясь мясом животных и молоком, а их шкуры и шерсть использовали для пошива одежды и других нужд. Лошади ими в основном использовались при пастьбе скота (конные пастухи), а так же как средство передвижения. При кочевом и полукочевом скотоводстве саками для выпаса животных, использовались пастбища древней дельты реки Или и песчаной пустыни
Сарыесик-Атырау. Для постоянного проживания в зимнее и летнее время, ими обустраивались стоянки, где строились жилища - землянки и полуземлянки, которые в дальнейшем группировались в отдельные поселения. Для водоснабжения этих поселений, ими использовались колодцы.

При просмотре спутниковых снимков, мною было выявлено восемь поселений, представленных линейными землянками в количестве от 16 до 260 единиц на одно поселение. Поселения землянок, на которых проживали саки, занимающиеся кочевым и полукочевым скотоводством, располагаются в следующих местах:

- среди песков между руслами Шет-Баканас и Кара-Баканас древней дельты реки Или поселение № 1 состоящее из 20 землянок (Фото 1, географические координаты 454ㄴ $44^{\prime \prime} \mathrm{N}$, $\left.75^{\circ} 33^{\prime} 05^{\prime \prime} \mathrm{E}\right)$, поселение № 2 состоящее из 20

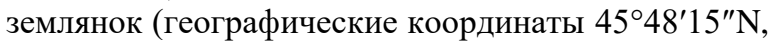
$\left.75^{\circ} 40^{\prime} 14^{\prime \prime} \mathrm{E}\right)$, поселение № 3 состоящее из 24 землянок (Фото 2, географические координаты $\left.45^{\circ} 48^{\prime} 22^{\prime \prime} \mathrm{N}, 75^{\circ} 40^{\prime} 35^{\prime \prime} \mathrm{E}\right)$;

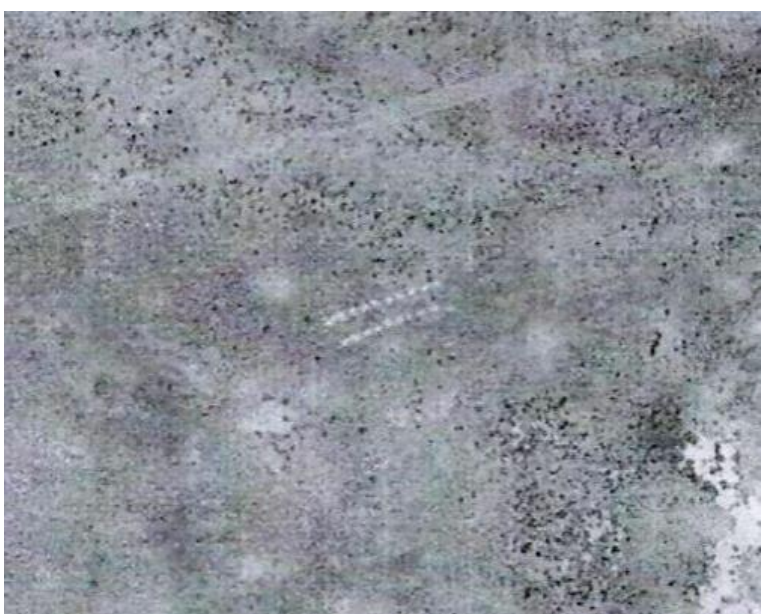

Фото 1. Поселение № 1

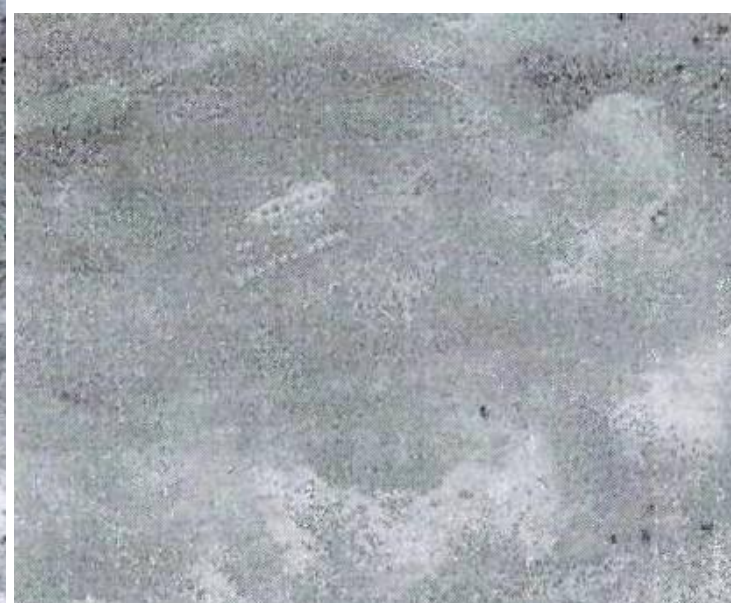

. Фото 2. Поселение № 3.

- среди песков пустыни Сарыесик-Атырау поселение № 4 состоящее из 16 землянок (Фото 3, географические координаты 452 $\left.6^{\prime} 57^{\prime \prime} \mathrm{N}, 76^{\circ} 10^{\prime} 01^{\prime \prime} \mathrm{E}\right)$, поселение № 5 состоящее из 260 землянок (Фото 4,

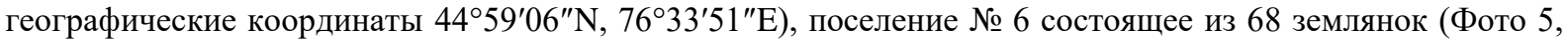

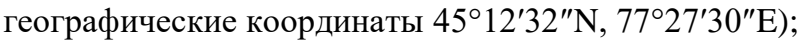

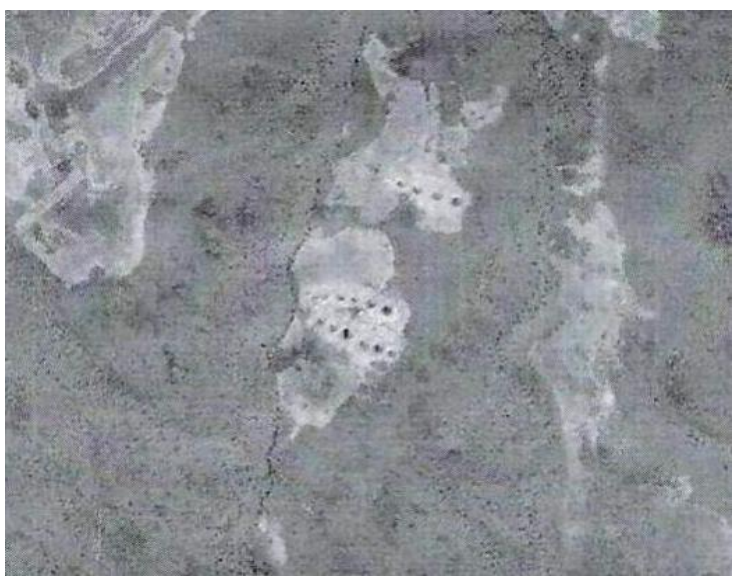

Фото 3. Поселение № 4.

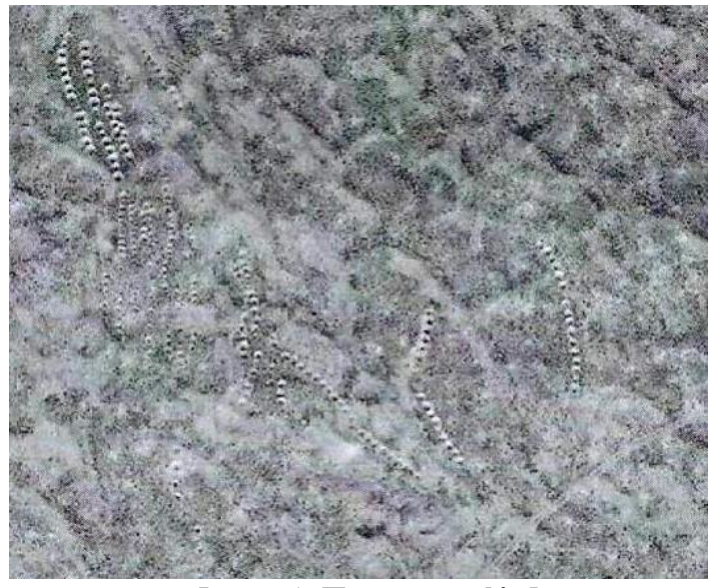

Фото 4. Поселение № 5. 


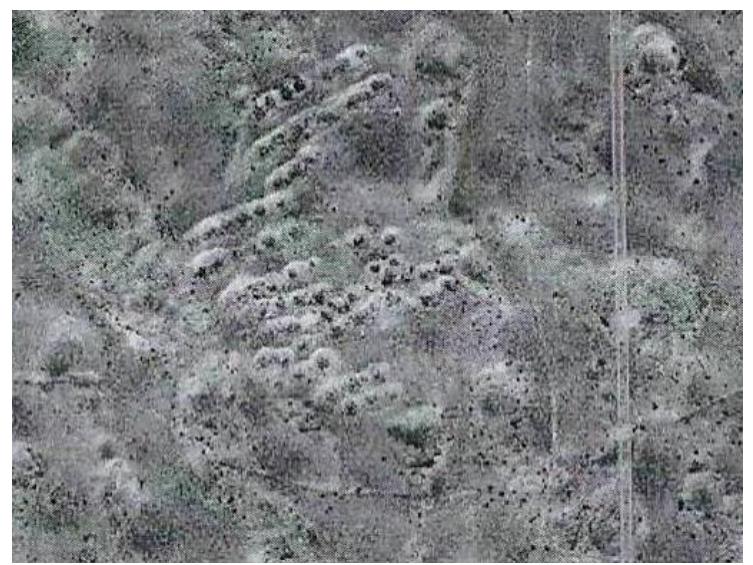

Фото 5. Поселение № 7.

- вдоль русла реки Или поселение № 7 состоящее из 100 землянок (Фото 6, географические

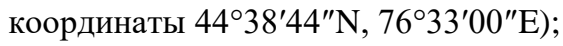

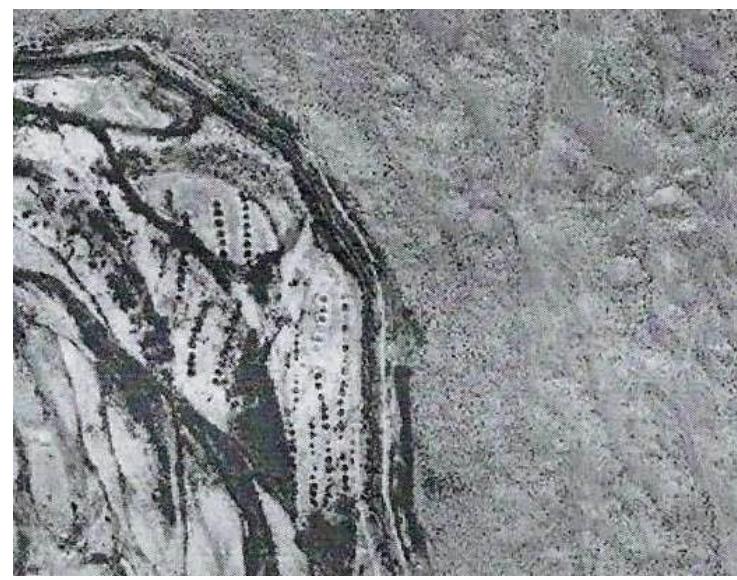

Фото 6. Поселение № 8.

- на юге пустыни Таукум на левом берегу реки Курты поселение № 8 состоящее из 260 землянок (Фото 7, географические координаты 4411'11"N, 76³1'56"Е).

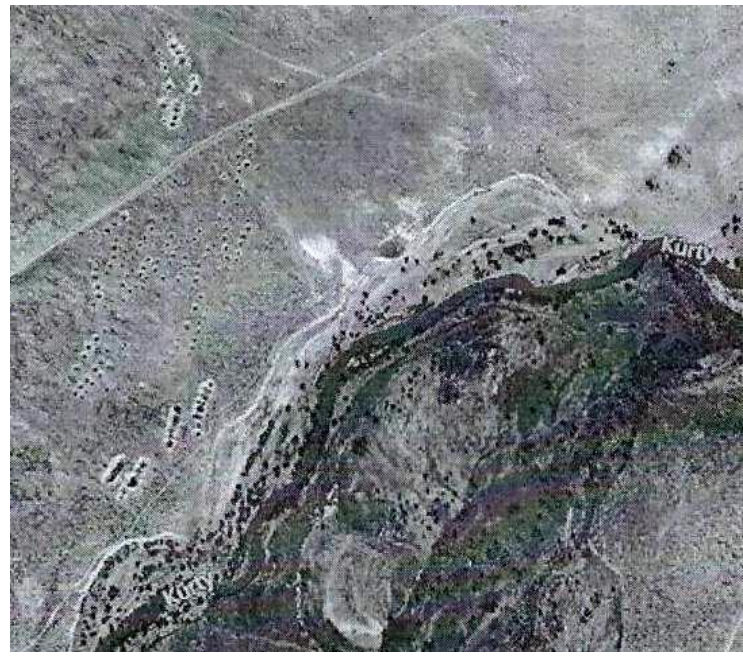

Фото 7. Поселение № 8.

В дальнейшем часть саков, проживающих вдоль реки Или и в её древней долине, стало переходить на оседлое проживание с ведением комплексного скотоводческо-земледельческого хозяйства при сохранении господствующей роли скотоводства. $\mathrm{C}$ помощью ирригационного земледелия, они на небольших площадях,

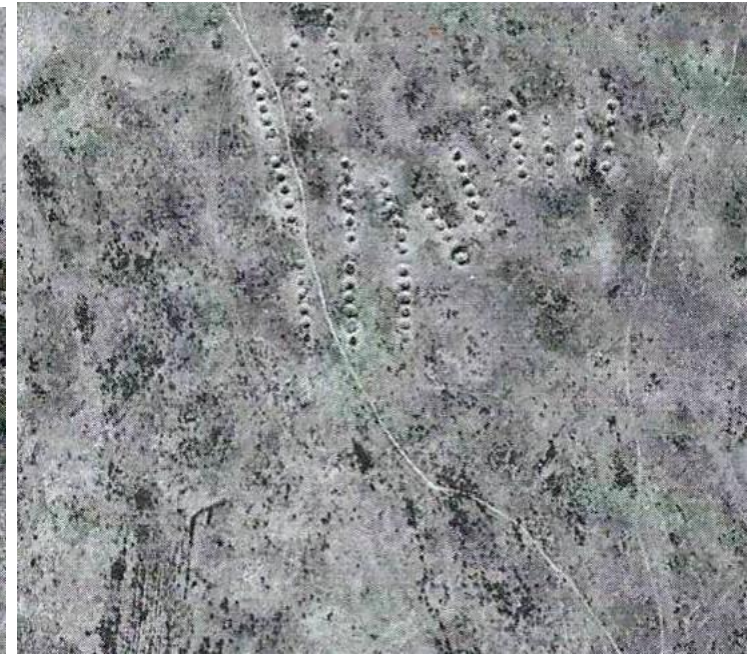

Фото 8.Поселение № 9.

выращивали растительную пищу, такую как просо, ячмень, пшеницу. Большинство посевных полей, орошалось с помощью каналов или весенних потоков. Одно из таких поселений № 9 состоящее из 100 землянок, расположено в восточной части дельты реки Или (Фото 8, географические координаты $\left.44^{\circ} 48^{\prime} 58^{\prime \prime} \mathrm{N}, 7^{\circ} 37^{\prime} 05^{\prime \prime} \mathrm{E}\right)$, в котором 
проживали саки, перешедшие на оседлый вид проживания с скотоводческо-земледельческим хозяйством. Еще много одиночных линий землянок находится вдоль левого берега реки Или, между современными поселками Казахстан и Ушарал. Выявленные мною древние поселения землянок на территории древней дельты реки Или и пустыни Сарыесик-Атырау, казахскими археологами еще не изучались и не описывались.

В конце II веке до н.э. (около 160-170 годах до н.э.) саки теряют свое военно-политическое господство среди племён Семиречья и в том числе в пределах древней дельты реки Или. В конечном итоге, они были вытеснены племенами древних усуней, пришедших из глубин Центральной Азии, образовавшие свое государство, которое просуществовало до $\mathrm{V}$ в. н.э. Это привело к переселению большей части саков с бассейна древней дельты реки Или в район Ферганы и Согдианы [3]. Меньшая часть саков была подчинена усуням, образуя единый обьединенный племенной союз на территории древней дельты реки Или, которую ранее занимали саки. Усуни, также как и саки, занимались кочевым и полукочевым скотоводством, а также комплексным скотоводческо-земледельческим хозяйством. Для проживания усунями на раннем этапе использовались сакские стоянки-поселения из землянок, которые они пополняли новыми землянками, расширяя их. В последствии усунями строились постоянные стационарные жилища с глинобитными и каменными стенами, которые встречаются на спутниковых снимках вдоль русел древней дельты реки Или и Курты.

C II в. н.э. на юге Семиречья и Южного Казахстана начинает функционировать Великий Шелковый путь, следовавший с Китая в Среднюю Азию, который проходил через Джунгарские ворота, следуя по территории проживания кочевых сакско-усуньских племен. Значительную роль в развитии его попутной торговли сыграли представители местных племен саков и усуней, которые оказывали помощь торговцам караванов в распространении шелка, меха, шкур, ковров и изделий из драгоценных металлов среди проживающего населения. Они также помогали сопровождать караваны через свои земли, предоставляя охрану, корм для питания скота и продукты для караванщиков, своих животных (лошадей и верблюдов) в качестве транспортного средства. Это способствовало укреплению торговых связей и взаимной заинтересованности кочевого населения местных племен с торговцами проходящих караванов Великого Шелкового пути, а так же появления небольшых поселений, для отстоя караванов.

В середине V в. н.э. территория Семиречья, которая на то время обладала многочисленными пастбищными лугами с богатой растительностью и водными источниками, расположенных в пределах древней дельты реки Или, а также в долинах крупных рек Каратала и Лепсы, превращается в одно большое поле битвы, за которое шли войны между многочисленными кочующими племенами. В результате этих войн, тюрские племена, пришедшие с запада, овладели всем Семиречьем, подчинив своей власти, проживающие кочевые и земледельческие сакско-усуньские племена. Их приход был не просто завоеванием, а крупной миграцией $\mathrm{c}$ цельей заселения обширных горностепных районов на севере и востоке Средней Азии, в том числе и Семиречья, через которое еще проходила часть караванных путей Великого Шелкового пути.

Вначале VI в. н.э. большая часть тюркоязычных племен, кочевавших по территории нынешнего Южного Казахстана, стали ощущать настоятельную потребность в объединении. Кочевое скотоводческое хозяйство сложно было вести без более или менее правильного распределения пастбищ по сезонам года, что приводило к постоянным столкновениям между кочующими и проживающими племенами, нарушению торговых связей с торговцами Великого Шелкового пути.

Это привело в середине VI в. н.э. к объединению большинства тюрскоязычных племен и племенных союзов, проживающих на территории от Байкала до Черного моря, включая земледельческие районы Средней Азии и Южного Прибалхашья, образуя мощное государство под названием Тюркский каганат [4]. Однако в конце VI в. Тюрский каганат, в составе которого находилось огромное количество кочевых племенных союзов, над которыми сложно было вести контроль, ввиду того, что между ними велась постоянная междоусобная борьба за власть в каганате, распадается на Восточный и Западно-Тюркский каганати. В Западно-Тюркском каганате, занимавшем территориию современного Казахстана, в том числе и Семиречья с древней дельтой реки Или, на то время племенную основу составлял союз тюркоязычных племен, заметную роль в котором играли племена карлуков, усуней и кангюев. Вследствии феодальных междоусобиц, проходившие в начале VII века, Западно-Тюркский каганат, как государство распался, и власть на территории Семиречья переходит к Тюргешскому каганату [4]. Население Тюргешского каганата в основном состояло из тюркоязычных племен, среди которых, основную роль играли племена тюргешей. В целом, Западно-Тюркский и Тюргешский каганаты представляли собой единую систему преимущественно кочевого и полукочевого способа ведения хозяйства. При кочевом и полукочевом скотоводстве в древней долине реки Или, в пределах которой находилось большое количество пасбищ с богатой растительностью, ими для проживания использовались землянки сакско-усуньских стоянок-поселений. Некоторая часть тюрок и тюргешей, проживающих на территории древней долины реки Или, переходила на оседлый образ жизни, где население занималось торговлей, ремёслами, скотоводством и землепашеством, с применением искусственного ирригационного орошения. Для проживания, они 
строили небольшие земледельческие поселения из стационарных квадратнообразной и юртообразной формы жилищ с глинобитными стенами, вдоль рек Или и Курты. Стоявшие в поселениях юрты, утеплялись вокруг грунтом или обкладывались саманной глиной, так что потом, при разборке на поверхности от них оставались разнообразные круги. Землянки и саманные хижины использовались местными жителями, как постоянные зимние жилища.

Наибольшее количество кругов от юрт, квадратов от саманных хижин и следов землянок, а также курганов, при просмотре спутниковых снимков, отмечается вдоль левого берега реки Или до современного поселка Ушокы и далее. Очевидно, еще с сакских времен, данная территория проживающими местными жителями использовались, для постоянного проживания, которые занимались зеледелием и скотоводством в районах рек Курты и Или. Для защиты своих поселений от разбойничних набегов враждующих кочующих племен, ими вдоль левого берега реки Или, было построено ряд оборонительных сооружений, представляющих собой четырехугольные в плане площадки, окруженные насыпными оплывшеми валами. Внутри них встречаются остатки стен квадратных жилых помещений с глинобитных стен. Одно из выявленных сооружений находится в 400 метрах на восток от современного поселка Казахстан (Фото 9, географические координаты $44^{\circ} 16^{\prime} 27^{\prime \prime} \mathrm{N}$, $76^{\circ} 42^{\prime} 43^{\prime \prime}$ Е.). Размеры его $110 \times 160$ метров. Второе находится на юго-западной окраине поселка

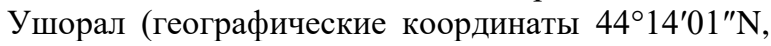
$\left.76^{\circ} 50^{\prime} 53^{\prime \prime} \mathrm{E}\right)$. Планировка его схожа с предыдущим сооружением и имеет размеры $110 \times 120$ метров. В настоящее время оно сильно разрушено и повреждено поселковыми дорогами. На восток от поселка Ушорал находятся еще два небольших сооружения размером 70х70 метров (географические координаты $44^{\circ} 14^{\prime} 01^{\prime \prime} \mathrm{N}$, $\left.76^{\circ} 50^{\prime} 05^{\prime \prime} \mathrm{E} ; 44^{\circ} 13^{\prime} 54^{\prime \prime} \mathrm{N}, 76^{\circ} 49^{\prime} 37^{\prime \prime} \mathrm{E}\right)$, а на юговосток три. Первые два имеют аналогичные размеры (географические координаты 44ำ $13^{\prime} 18^{\prime \prime} \mathrm{N}$, $\left.76^{\circ} 51^{\prime} 54^{\prime \prime} \mathrm{E} ; 44^{\circ} 12^{\prime} 50^{\prime \prime} \mathrm{N}, 7^{\circ} 51^{\prime} 55^{\prime \prime} \mathrm{E}\right)$, третье чуть больше - 90х90 метров и очень разрушенное водными потоками реки Или при наводнениях (географические координаты $44^{\circ} 10^{\prime} 32^{\prime \prime} \mathrm{N}$, $\left.76^{\circ} 54^{\prime} 20^{\prime \prime} \mathrm{E}\right)$.

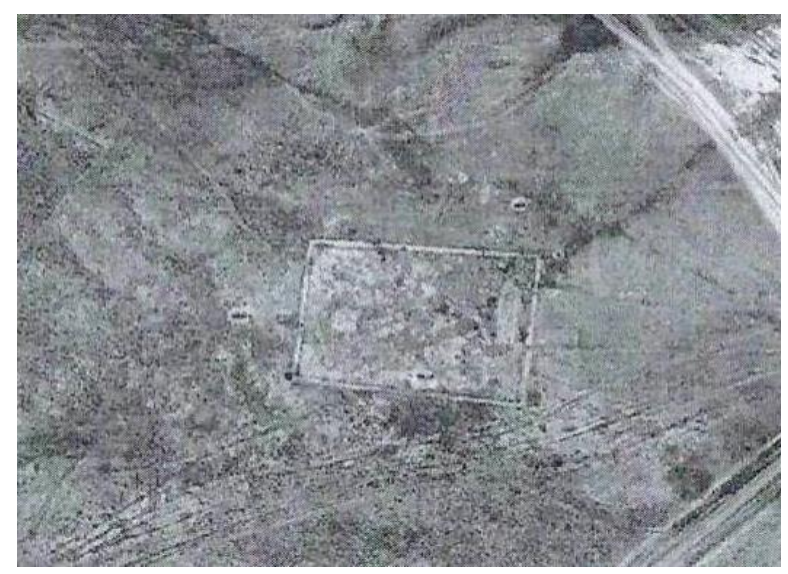

Фото 9. Неизвестное поселение у поселка Казахстан.

Тюрками еще вдоль движения торговых караванов, строились поселения-городища, так называемые караван-сараи или торткули, которые являлись на то время центрами местных торговцев, ремеслиников, земледельцев и служили местами временных стоянок проходящих торговых караванов. Они представляли собой прямоугольные площадки, вокруг которых возводились стены с башнями или насыпались земляные валы. Вокруг крупных городищ рылись защитные рвы и каналы от притоков окружающих рек, для снабжения их водой. Располагались они в основном друг от друга на расстоянии фархаса одного дневного перехода груженного товарами каравана, который равнялся в среднем 35-45 км. В целом, оседло-земледельческий тип хозяйствования был тесно связан с кочевым и полукочевым. Земледельцы часто еще занимались отгонно-пастбищным скотоводством, в процессе которого, они сбывали свои товары и продукты кочевникам, укрепляя тем самым связь между кочевыми и оседлыми жителями каганатов.

В связи постоянными изнурительными войнами, происходившими между каганатами и окружающими племенами, в середине VIII в. н.э., тюрские племена потеряли власть на территории Семиречья. В это время здесь развернулась борьба за тюргешское наследство между карлуками, пришедшими с восточной части Казахстана и тюркоязычными огузами, отдельные группы которых, входящие в состав Тюрского каганата, проживали в степной зоне юго-восточного побережье оз. Балхаш. Огузы в этой борьбе потерпели поражение, и значительная их часть вынуждена была покинуть Семиречье, переселившись в предгорья Каратау и долину реки Чу, а в дальнейшем перейти в Сырдарьинский регион. Карлуки остались в Семиречье, создав раннефеодальное государство - Карлукский каганат, заселив юго-восточную часть территории Семиречья и предгорье Джунгарского Алатау. Они, 
также как и тюрки, в основном занимались полукочевым скотоводством, выращивая курдючных овец, лошадей, верблюдов и частично землепашеством в долинах рек Каратал и Лепсы, выращивая разнообразные зерновые культуры. Животноводческая и земледельческая продукция удовлетворяла не только их внутренние потребности, но и использовалась для торгового обмена с тоговцами проходящих караванов Великого Шелкового пути.

Однако незначительная часть кочевых огузких племен все же осталась в Семиречье и поселилась в низовьях древней дельты реки Или, имея близкие контакты с живущими огузкими племенами долины реки Чу. Для проживания ими на раннем этапе использовались небольшие саксо-усуньские и тюрские поселения, разбросанные по всей территории дельты реки Или и юго-западного побережья озера Балхаш, состоящие из юрт, землянок и квадратных саманных хижин, которые они пополняли новыми землянками и жилищами, расширяя их, а также строя небольшие поселениягородища. Они хорошо просматриваются на спутниковых снимках вдоль русел-баканасов древней долины дельты реки Или и реки Курты.

Поселившиеся в то время на территории древней дельты реки Или огузы, стали интенсивно заниматься поливным земледелием, с применением искусственного ирригационного орошения, выращивая просо, пшеницу и другие сельскохозяйственные культуры [5]. При этом ими использовались каналы, прорытые в предшествующие сакско-усуньские и тюрские времена. Кроме магистральных каналов и арыков, огузами строились еще водохранилища с плотинами для поднятия уровня воды в рукавах и протоках дельты реки Или, которая потом по мелким каналам-оросителями и устройствам для направления воды, распределялась по нужным руслам для орошения земель. О развитии ирригационного земледелия в этих районах, свидетельствует наличие большого количества ирригационных полей с каналами и арыками, остатки которых на сегодняшний день встречаются практически по всей территории древней дельты реки Или, начиная от п. Бакбакты и до южного берега озера Балхаш. В сочетании с поливным земледелием, огузы еще занимались отгонным скотоводством, разводя стада лошадей, верблюдов, овец и коз. Лошадь в то время, у огузов являлась основным средством передвижения и ведения сельскохозяйственных работ, а также использовалась в военных походах. Овцеводство было распространено повсеместно. Кроме основного продукта питания мяса, оно давало еще кожи, шкуры, шерсть, применявшиеся для изготовления одежды, постельных принадлежностей, ковров, войлочных изделий, утепления юрт и т.д. Выращенных верблюдов и лошадей, огузы обменивали на товары с торговцами проходящих караванов. Среди оседлых групп огузов имелись не только земледельцы и скотоводы, но и рыболовы, занимавшиеся рыбалкой в рукавах древней реки Или и на южном берегу западной части озера Балхаш, называемого ими Горгуз. Помимо земледелия, скотоводства и рыбалки, ими велась еще добыча каменной соли, встречающейся в виде пластов на поверхности солонцов в прибрежной западно-южной зоне Балхаш-Алакольского водоема, между долинами рек древней Или и Каратал. В те времена, соль имела очень большое значение среди оседлых кочевых племен, живших в земледельческих поселениях и городищах Семиречья, Средней Азии, Китая, и приравнивалась к цене золота. Благодаря своим консервирующим свойствам, ее в большинстве случаев использовали при заготовке, хранении и транспортировке мяса, шкур и других скоропортящихся продуктов.

В этот период, с наступлением глобального потепления, у проживающих в Северном Прибалхашье кимакских кочевых племен, стали появляться трудности с выращиванием сельхозкультур, используемых ими для своих нужд и развития животноводства. Такая возникшая ситуация, способствовала к возникновению военных конфликтов между ними и огузами, которые сопровождались частыми набегами на земледельческие поселения огузов, поселившихся в ранее доступных для этих племен земледельческих оазисов древней долины дельты реки Или. Для свободного перемещенния на территорию Южного Прибалхашья за сельхозпродуктами и ведения обменной торговли, северо-прибалхашскими кимакскими племенами в те времена использовался Токрау-Илийский перешеек, который разделял современное озеро Балхаш Балхаш-Алакольской впадины на две части.

С целью защиты своих земледельческих сельхозугодьей от этих постоянных набегов североприбалхашских кимакских, а так же восточных южно-прибалхашских карлукских племен, огузы вынужденные были построить новые оборонительные сооружения в виде городищкрепостей, в местах расположения тюрских торговых земледельческих и караванных поселений-городищ. Основная часть этих городищкрепостей, располагалась в северо-восточной части древней долины реки Или, между руслами КараБаканас и Шет-Баканас, с помощью которых они контролировали переходы враждующих племен через Токрау-Илийский перешеек и с восточной части южного побережья озера Балхаш. К ним относятся известные на сегодняшний день городища Актам, Агашаяк, Карамерген, а также выявленное мною в процессе изучения спутниковых снимков неизвестное городище, расположенное на южном берегу озера Балхаш севернее русла Ортасу. Остальные небольшие поселения-городища с валами остались без изменения и размещались в виде цепочки, вдоль юго-восточной части древней дельты реки Или и дальше вдоль русла реки Курты до предгорий Заилийского Алатау, которые использовались огузами для временных стоянок проходящих торговых караванов, а также для временного 
проживания и убежищ на случай набегов банд грабителей и разбойников кочевых племен карлуков (Рис 1).

В дальнейшем огузы примирились с окружающими карлукскими и кимакскими кочевыми племенами, частично смешавшись с ними. Это привело последних, перейти к полуоседлому образу жизни и занятию земледелием в долинах крупных рек Токрау, Коктал, Лепсы и их притоках, а также скотоводством, разводя овец, коз, лошадей и вьючных верблюдов, спрос на которых в это время все больше возрастал.

В начале X века после распада Карлукского каганата, на территории Семиречья возникло новое государство Караханидов [4]. В его состав вошли все проживающие тюрские племена в Средней Азии, Южном Казахстане и Семиречье, а также тюркоязычные огузы древней долины реки Или. Просуществовало оно до середины XII века, которое вследствии Монгольского нашествия было разбито и разрушено.

Большую роль в формирование политического, экономического, культурного, религиозного устройства Западно-Тюрского, Тюргешского и Карлукского каганатов, а так же государства Караханидов, послужило еще прохождение через их территории трасс торговых караванов Великого Шелкового пути, следовавших из Китая в Среднюю Азию. Власти каганатов, контролировавшие проходящие караваны, получали неплохую прибыль от торговли с ними, покупая их товары или сбывая свои, а также за оказанные услуги, связанные с сопровождением, обслуживанием и охранной при прохождении через их территории. По пути следования торговых караванов распространялись привозимие с Востока и Запада шелк, полотна, ковры, керамика, изделия из драгоценных металлов, луки, стрелы, сельхозорудия и другие товары первой необходимости, в обмен на товары местного производства.

На протяжении столетий на трассах следования Шелкового пути торговцами устраивались временные остановки, в дальнейшем превращающиеся в караван-сараи или поселениягородища, часть из которых впоследствии становились крупными городищами и городами, сыгравшими важную роль в формировании городской феодальной культуры тюрков Семиречья и Южного Казахстана. Первые поселения-городища на его пути, как отмечалось выше, появились еще в сакско-усуньское время, где в самых удобных местах прохождения местных торговых караванов через 35-50 км строились караван-сараи, с конюшнями и складами для хранения транзитных грузов. Вокруг этих поселений насыпались валы и выкапывались рвы, для защиты от нападений банд грабителей и разбойников враждующих кочевых племен. Наибольшего своего развития эти поселения- городиша начали приобретать в VII-IX веках, когда трассы Великого Шелкового пути набирали наиболее оживленного движения, что способствовало к возникновению на них, ряда крупных городских торговых и административных центров, таких как Суяб, Навакет, Тараз, Испиджаб, Тальхиз и небольших городищпоселений, основой для которых послужили земледельческие поселения. Городское население в основном занималось торговлей и разнообразными ремеслами, а кочевое и полукочевое скотоводством и землепашеством на землях древней дельты реки Или и других рек, впадающих в озеро Балхаш.

В то время здесь проходило две трассы Великого Шелкового пути (Рис 1). Основная трасса пролегала с внутреннего Китая через город Дуньхуа на оазисы Хами и Турфан, по северной оконечности пустыни Такла-Макан, в сторону предгорья Заилийского Алатау вдоль правого берега реки Или и достигала города Тальхиз (Талгар), который был центром транзитной торговли [6]. Дальше караваны следовали к большим торговым центрам Южного и Среднего Казахстана - Суяб, Навакет, Тараз и другим городам. Город Суяб был столицей западных тюрок, затем тюргешей, карлуков и служил торговыми воротами, для караванов Шелкового пути следующих на территорию Южного Казахстана, Средней Азии и Китай. Вторая трасса проходила от оазиса Хами в сторону Долины Шихо через Джунгарские ворота в долину Тентека. Дальше она следовала по южной части Семиречья через городища Каялык, Ики-Огуз, Чингильды до городища Тальхиз, соединяясь с маршрутом основной трассы Шелкового пути, идущей в Суяб.

Многими исследователями считалось, что караваны от городища Чингильды к Тальхизу или обратно, проходили через реку Или в районе Капчагайского ущелья. Но движение караванам по скальным выходам Капчагайского ущелья и крутым берегам, очевидно, было сложным. При просмотре аэрофотоснимков, мною было выявлено южнее поселка Нура на левом берегу реки Кутенсай в урочище Жаксылык остатки торткуля, расположенного между городищами Тальхиз и Чингильды на расстоянии около 40 км в обе стороны, что соответствует одному дню прохождения каравана (географические

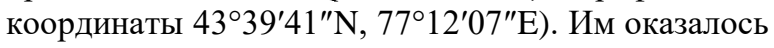
торткуль (городище) Жаксылык, которое изучалось археологами в 1967 году [8]. Торткуль представляет собой четырехугольный в плане участок, размером 100x100 метров, ориентированный по сторонам света, окруженный оплывшей саманной стеной высотой около 2 м. Со всех сторон площадь торткуля окружена земляным валом размером 450 на 470 метров, который на сегодняшний день сильно оплывший, задернованный и распаханный (Фото 10). 


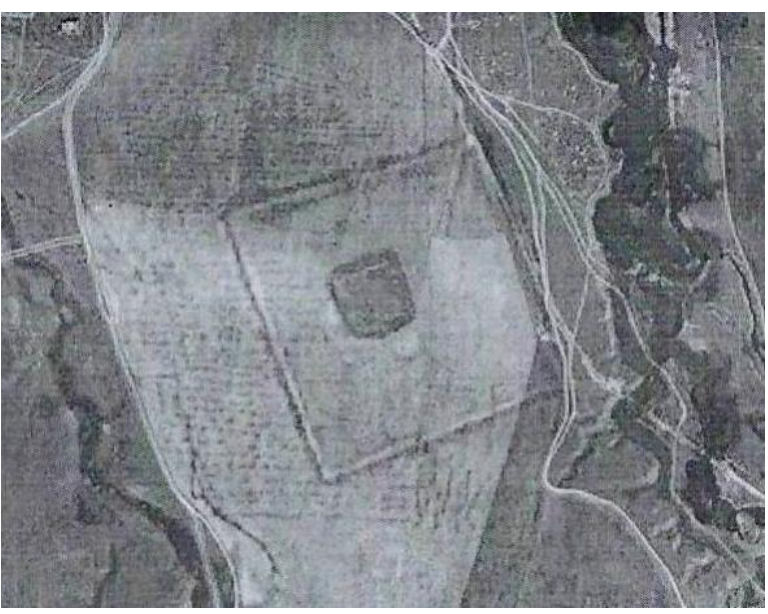

Фото 10. Торткуль (городище) Жаксылькк.

Очевидно, это поселение служило пунктом временной остановки для проходящих транзитных и внутренних торговых караванов, идущих по равнинной территории долины реки Или, между этими городищами. В то время Капчагайского водохранилища не было и уровень воды в реке Или был не высоким, что позволяло караванам свободно переходить её в мелководных местах.

Самый большой пик роста городов и поселений-городищ на территориях Семиречья и Южного Казахстана, приходился на период IX-X вв, в которых происходит рост оседлого городского населения, занимавшееся торговлей и ремеслом. В результате этого, стал, повышался спрос на продукты животноводства и земледельческих культур, необходимых для питания городского населения, людей обслуживающих караваны и караванных животных, изготовляющих ремесленные орудия труда, а также для торговли своими товарами с другими странами. Своих сельскохозяйственных и животноводчиских продуктов, выращенных вокруг городищ и поселений, не хватало. Это привело огузов к расширения скотоводческого полукочевого хозяйства и увеличению выращивания сельхозкультур в древней долине реки Или, с применением систем искусственного орошения.

В итоге, большая часть кочевых и полукочевых огузов, проживающих на этих землях, стала переходить к постоянному оседлому проживанию, создавая в долине древней реки Или разрозненные небольшие поселения и городища, занимаясь выращиванием земледельческих и животноводческих продуктов, а также добычей соли, охотой и рыбалкой, которые ими потом сбывались на базарах крупных городов или поселках-городищах. От этих городов и поселковгородищ, по всей древней долины реки Или и прилегающим к ней территориям, расходились небольшие ответвления караванных дорог и троп, по которым местными торговцами обслуживались небольшие земледельческие и животноводческие степные поселения и зимовки, а также собирались местные товары для сбыта торговцам транзитных караванов, движушщих по трассам Шелкового пути. Торговля в основном производилась в натуральной форме, в виде обмена и достигала больших масштабов. Так, например представители местных племен проходящим торговцам отдавали по нескольку десятков тысяч лошадей, а в обмен получи до 100 тыс. кусков шелка, который высоко ценился среди коренного населения.

Таким образом, помимо транзитных торговых центров расположенных вдоль основных трасс Шелкового пути, проходящих через территорию Семиречья, здесь стали формироваться земледельческие центры-городища, окруженные валами с башнями, такие как Актам, Агашаяк, Карамерген, Бояулы и другие незвестные городища, которые впоследствии использовались для стоянок проходящими торговыми караванам.

В связи с увеличением поливных земледельческих хозяйств в пределах древней дельты реки Или и на других территориях Семиречья, возникла необходимость в использовании качественных орудий труда, керамики, изделий из шерсти, кожи, металлов и бронзы, это привело к появлению в крупных городах и городищах Семиречья групп мастеровремесленников из приезжих людей и местного населения, занимавшихся их изготовлением и продажей на городских базарах. Своих производственных материалов для полного обеспечения ремесленных мастерских стало не хватать. В то время районы Центрального и Восточного Казахстана были богатыми черными, ияетными, благородными ископаемыми металлами и драгоценными камнями, а также скотом, шерстью и кожами, в которых нуждались многие крупные города Южного Казахстана $и$ Семиречья. Для налаживания торговли с земледельческими, животноводческими и соляными районами древней дельте реки Или, а так же с регионами Центрального и Восточного Казахстана, в начале VIII века от городища Тальхиз и торговых центров Навакет, Суяб, Баласагур, расположенных вдоль основной трассы Великого Шелкового пути, было проложено несколько ответвлений караванных путей. Привозимые земледельческие и животноводческие продукты, а также производственные материалы поставлялись местным торговцам на городских рынках и 
мастерам-ремеслиникам, для производства орудий труда и других изделий. Часть поступающих земледельческих и животноводческих продутов, добытой соли, а также изготовленных производственных материалов, сбывались местными торговцами проходящим торговым караванам Шелкового пути, которые шли через Семеречье в Среднюю Азию и Китай. Еще ими загружались торговые караваны, следующие в Северный Казахстан через Токрау-Илийский перешеек, где они выходили на северную трассу Великого Шелкового пути, продолжая свое движение в сторону Алтая и Монголии или Южного Приуралья и Причерноморья. Таким образом, богатые скотом, шерстью, кожами, сельхозпродуктами и солью районы древней дельты реки Или, были вовлечены в систему торговых международных связей Великого Шелкового пути.

При изучении спутниковых снимков и анализе имеющихся археологических материалов по этим районам, мною было установлено, что в древнюю дельту реки Или, проходил не один торговокараванный путь, а несколько, которые имели разное предназначение. Одни из них были транзитными и направлялись в районы Северного, Центрального и Восточного Казахстана или обратно в районы Южного Казахстана и Семиречья. Другие использовались с целью загрузки местными товарами, выращенными и добытыми на территории древней дельты реки Или, которых здесь на то время было в избытке, для вывоза их на рынки крупных торговых центров Юго-Западного Казахстана и Семиречья, таких как Испиджаб, Кедер, Отрар, Янгикент, Тараз, Баласагур, Талгар и Каялык, расположенных вдоль основного направления Великого Шелкового пути. Так же большое значение в направлениях этих торгово-караванных путей имело время года, по чьей территории проходил маршрут, и кто ее контролировал.

Одно из ответвлений Шелкового пути, пересекавшее всю древнюю долину реки Или с юго-запада на север, следовало в район расположения земледельческих городищ Актам, Агашаяк и Карамерген (Рис. 1). Начиналось оно очевидно еще в тюрские времена от городища, которое находилось в районе современного поселка Узунагач, расположенного на основной трассе между Суябом и Тальхизом (географические координаты $\left.43^{\circ} 12^{\prime} 47^{\prime \prime} \mathrm{N}, 7^{\circ} 20^{\prime} 07^{\prime \prime} \mathrm{E}\right)$. Дальше путь данного ответвления следовал вдоль реки Курты и её притокам через небольшие поселения-городища, находившихся на местах современных поселков Казыкбек бека (географические координаты $\left.43^{\circ} 36^{\prime} 15^{\prime \prime} \mathrm{N}, 76^{\circ} 18^{\prime} 09^{\prime \prime} \mathrm{E}\right)$ и Акший (географические координаты $44^{\circ} 00^{\prime} 09^{\prime \prime} \mathrm{N}, 76^{\circ} 18^{\prime} 38^{\prime \prime} \mathrm{E}$ ) до реки Или. В то время, жители этих поселений-городищ занимались земледелием и скотоводством. В настоящее время, данные поселения-городища были разрушены в процессе развития современных поселков. При просмотре спутниковых снимков на окраинах этих поселков встречаются квадратные следы от жилых саманных зданий и площадок с валами тех времен, очевидно служивших местом для стоянок и загрузки местными товарами проходящих караванов.

Из поселка Акший дорога дальше шла вдоль берегов рек Курты и Или до городища Бояулы. Местами для временной остановки караванов служили небольшие поселения, так называемые торткули, выявленные мною с помощью спутниковых снимков. Большая их часть была обнесена земляными валами без заметных следов долговременных построек. Скорее всего, они служили временными укрытиями, где проживающее кочевое население размещалось в юртах и палатках вместе со скотом, укрываясь во время вражеских набегов. Названия их на сегодняшний день до нас не дошли, так как эти поселения казахскими археологами еще не изучались. Располагались они в большинстве случаев друг от друга на расстоянии 35-45 км, что отвечало одному дневному переходу груженного товарами каравану. Первое неизвестное поселениеторткуль № 1, находилось в 30 км от поселка Акший на правом берегу реки Курты (Фото 11, географические координаты $44^{\circ} 12^{\prime} 18^{\prime \prime} \mathrm{N}$, $\left.76^{\circ} 34^{\prime} 40^{\prime \prime} \mathrm{E}\right)$. Поселение-торткуль представляет собой четырехугольный участок размером 90х150 метров, окруженный со всех сторон оплывшим валом, ориентированным углами по сторонам света. Въезды на территорию торткуля расположены в северном углу и на западной стороне вала. Севернее в 200 метрах от торткуля, вдоль берега реки Курты находилось поселение, о чем свидетельствуют многочисленные квадратообразные остатки от жилищ. 


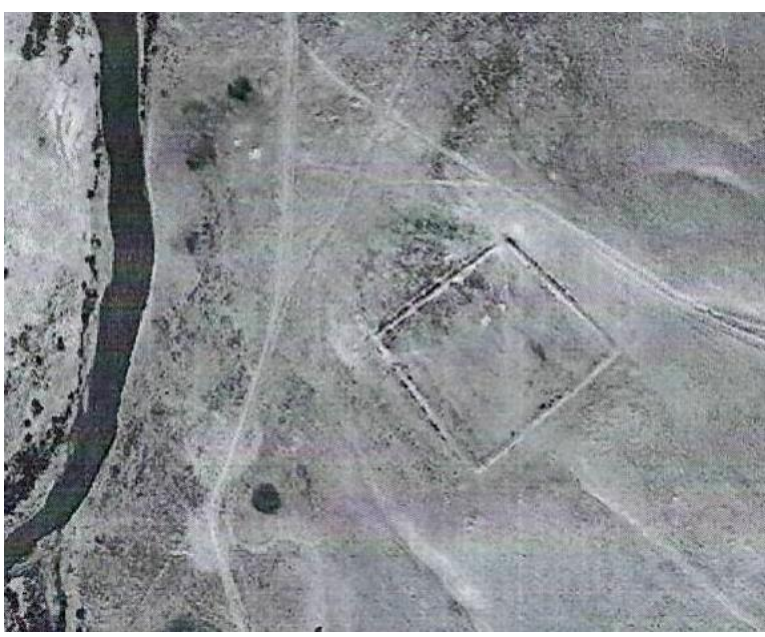

Фото 11. Неизвестное поселение-торткуль № 1.

Следующее неизвестное поселение-торткуль № 2, располагалось в 40 км на север от описанного выше неизвестного поселения-торткуля, на левой стороне долины реки Или у границы с пустыней Таукума (Фото 12, географические координаты $\left.44^{\circ} 34^{\prime} 33^{\prime \prime} \mathrm{N}, 7^{\circ} 32^{\prime} 03^{\prime \prime} \mathrm{E}\right)$. Оно также представляет собой четырехугольную площадку размером 100x100 метров, окруженную оплывшим валом и ориентированным углами по сторонам света. Въезды на её территорию находятся с трех сторон от долины реки Или.

Далее путь следовал по левому берегу долины реки Или и выходил на мелководные участки, где караваны могли свободно переходить реку Или вброд на правый берег, продолжая своё движение в сторону неизвестного придорожного караван-сарая № 3 (Фото 13, географические координаты

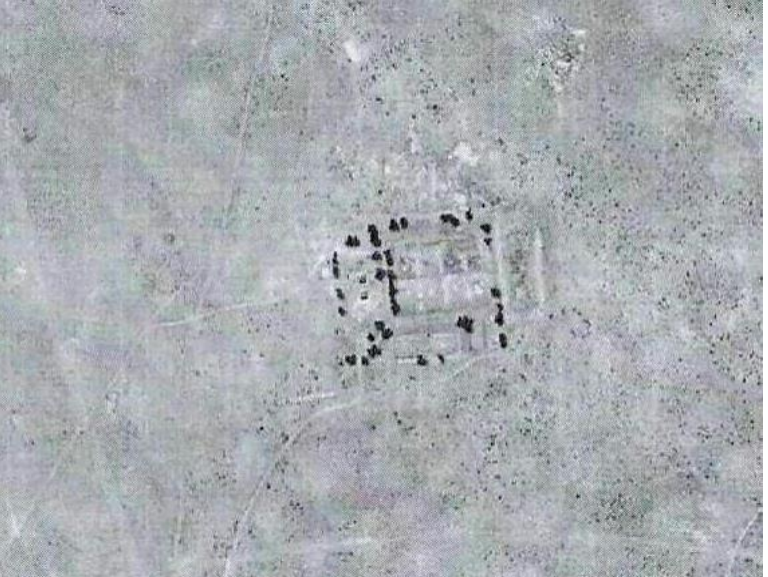

Фото 13. Неизвестный караван-сарая

Из описываемого караван-сарая дальше караванный путь проходил вдоль правого берега долины реки Или к городищу Бояулы, получившее своё название от урочища Бояулы, которое в то время, находилось в центре долины, на левом берегу одного из русел, в 20 км к северу от поселка Баканас (Фото 14, географические координаты 44 $\left.55^{\prime} 22^{\prime \prime} \mathrm{N}, \quad 76^{\circ} 07^{\prime} 39^{\prime \prime} \mathrm{E}\right) . \quad$ Первые исследовательские работы этого городища проводились в 1962 году Семереченской археологической экспедицией под руководством

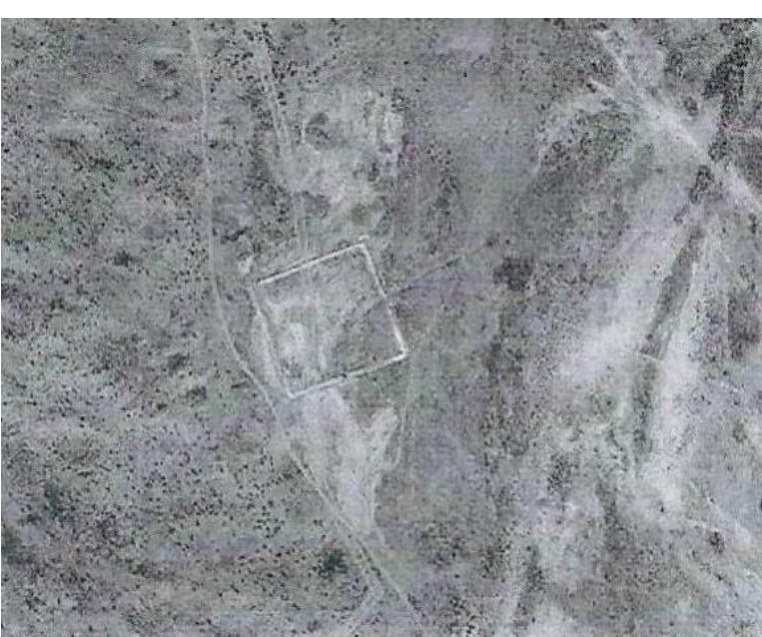

Фото 12. Неизвестное поселение-торткуль № 2.

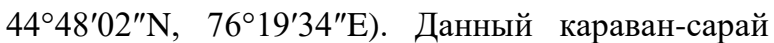
расположен в 30 км на север от второго неизвестного поселения-торткуля среди песков и в 2,5 км восточнее современного поселка Баканас. Он был открытого вида, площадью 150×170 метров и представлял собой комплекс с десяти хозяйственных дворов квадратной и прямоугольной формы, где находились конюшни, склады и места для проживания. Стены дворов, очевидно, были глинобитные и в настоящее время разрушенные, оплывшие и присыпаны песками пустыни. В западной части караван-сарая, отмечаются фрагменты магистрального канала, который был проложен от одного из русел реки Или и служившего в то время, для подачи воды на его территорию.

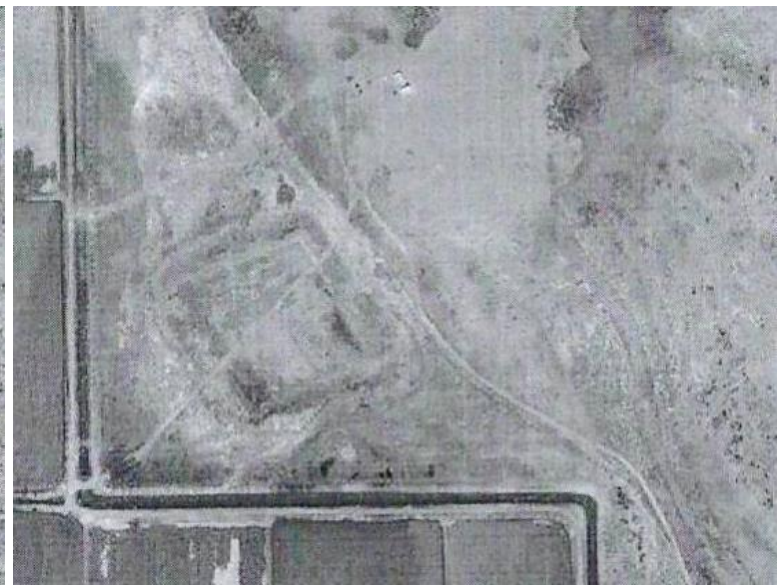

№ 3. Фото 14. Древнее городище Бояульы.

К.А.Акишева [7]. В плане оно представляет собой четырехугольную площадку, ориентированную углами по сторонам света и окруженной саманными стенами высотой в 2 м. Юго-восточная и северо-западная стороны стены имеют длину 100 м., а северо-восточная и юго-западные стороны 115 м. Обнаруженная при раскопках городища керамика, датирует время его существования X-XII вв, что отвечает периоду проживания огузов. Однако при просмотре спутниковых снимков у западной, северной и восточных частях описанного 
городища, отмечаются разрушенные и оплывшие остатки валов, что увеличивает размеры первоначальной площадки до $150 \times 150$ метров. Очевидно, городище Бояулы было построено тюрками в начале VIII века, а после прихода огузов в начале X века, перестроено.

Из городища Бояулы дорога выходила в древню долину реки Или к известным городищам Актам, Агашаяк и Карамерген. Городище Актам располагалось в 80 км от городища Бояулы. Между ними находилось большое количество древних русел, существующей в то время реки Или, ирригационных полей с каналами и арыками, которые затрудняли продвижение торговых караванов, а так же ряд небольших земледельческих поселений (географические координаты $45^{\circ} 14^{\prime} 55^{\prime \prime} \mathrm{N}, 75^{\circ} 52^{\prime} 07^{\prime \prime} \mathrm{E} ; 45^{\circ} 13^{\prime} 10^{\prime \prime} \mathrm{N}$, $\left.75^{\circ} 56^{\prime} 50^{\prime \prime} \mathrm{E} ; 45^{\circ} 13^{\prime} 32^{\prime \prime} \mathrm{N}, 75^{\circ} 02^{\prime} 01^{\prime \prime} \mathrm{E}\right)$. Большинство этих поселений, состоящих из нескольких домов с глинобитными стенами, были расположены посредине между городищями Бояулы и Актам, что позволяло их использовать для временной остановки проходящим караванам. Еще здесь по спутниковым снимкам просматривается квадратнообразная площадка со слабовыраженными оплывшими валами, ориентированная углами по сторонам света и размером около 80x80 метров (географические координаты $\left.45^{\circ} 11^{\prime} 39^{\prime \prime} \mathrm{N}, 7^{\circ} 55^{\prime} 10^{\prime \prime} \mathrm{E}\right)$. Очевидно на раннем этапе освоения тюрками этих земель, здесь находилось небольшое поселение-торткуль. Но в дальнейшем, в связи с расширением огузами ирригационных полей, что привело к сложностям при прохождении груженых караванов, оно, возможно, потеряло свое предназначение и для временных стоянок караванов стали использоваться доступные вышеприведенные зеледельческие поселения.

Городище Актам представляет собой двойное квадратное сооружение. Первоначально в тюрские времена в начале VIII века оно представляло собой площадку размером 250х300 метров, ориентированной по сторонам света и укрепленной небольшим валом, оплывшим на сегодняшний день. Тюрками оно, очевидно, использовалось как земледельческое поселение и использовалось для временной стоянки проходящих торговых караванов описываемого ответвления. После прихода огузов, на его месте было построено новое сооружение - городище-крепость, служившее еще для защиты от набегов враждующих кимакских племен (Фото 15, географические координаты 45 $\left.32^{\prime} 29^{\prime \prime} \mathrm{N}, \quad 75^{\circ} 46^{\prime} 30^{\prime \prime} \mathrm{E}\right)$. Площадь вновь построенной крепости имела размеры 180х170 метров и была укреплена саманными стенами в виде вала с башнями, которая сейчас разрушенная и оплывшая. В 1961 г. исследования вновь построенного городища проводилось Семиреченской археологической экспедицией под руководством академиков К.А.Акишева, К.М. Байпакова, а в 1997 г. Южно-Казахстанской комплексной археологической экспедицией под руководством академика К.М. Байпакова [7]. В ходе раскопок было обнаружено несколько десятков осколков керамической посуды, бронзовых и стеклянных изделий датируемых XXII вв., принадлежащих проживающим огузам.

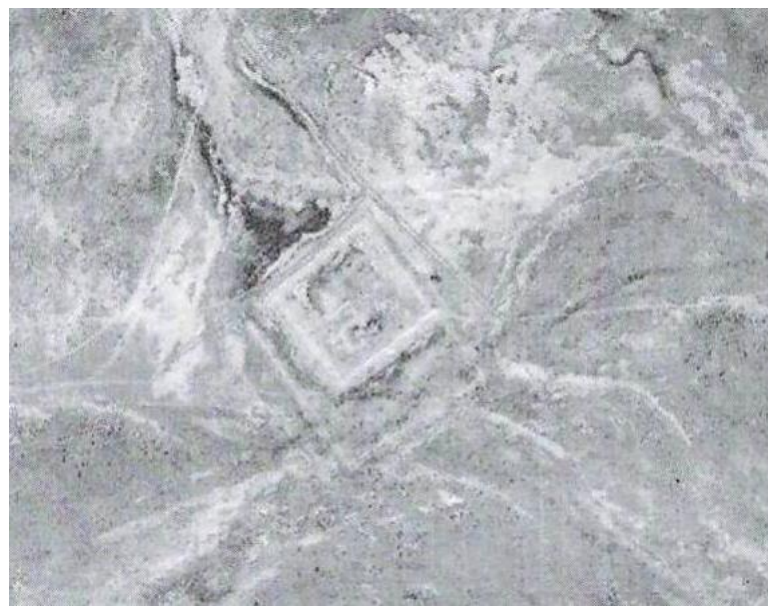

Фото 15. Древнее городище Актам.

Из городища Актам путь дальше шел между руслами протоков долины реки Или, песчаных барханов и иррагиоционных полей к городищу Агашаяк, которое находилось в 45 км (Фото 16, географические координаты $45^{\circ} 54^{\prime} 27^{\prime \prime} \mathrm{N}$, 7539'44"Е). Его планировка имеет большое сходство с городищем Актам. Первоначально в тюрское время, городище Агашаяк, очевидно, представляло собой квадратное в плане сооружение, размером $350 \times 350$ метров, огражденное небольшим валом. С приходом

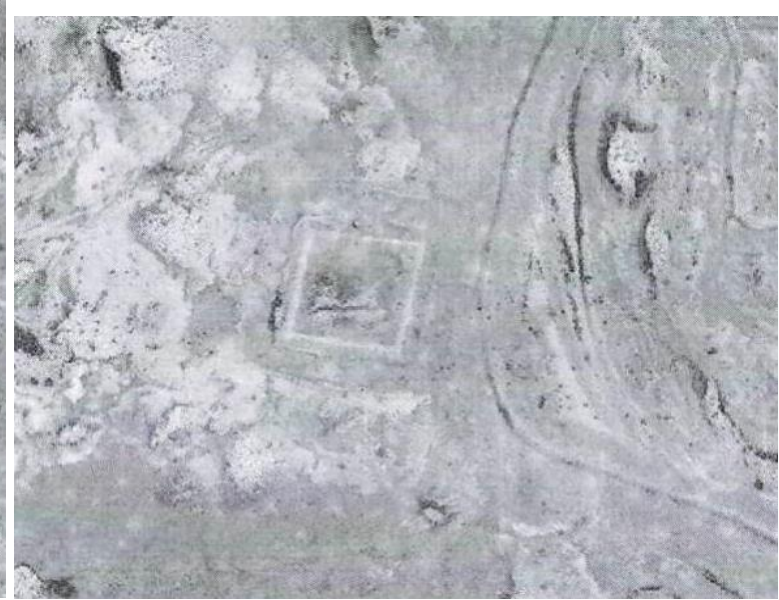

Фото 16. Древнее городище Агашаяк.

огузов, на его месте, также как на городище Актам, было построено новое крепостное сооружение, обнесенное саманными стенами, с башнями по углам и периметру. Сегодня стены крепости оплыли и превратились в вал с покатыми закругленными стенками. Размеры городища $200 \times 200$ м. Вода для нужд, проживающих в городище людей, поступала по каналу от протекающей протоки реки Ортасу, в 100 метрах. Она также наполняла канал, который был вырыт огузами вокруг крепостной стены городища, с 
целью защиты от нападений. При проведении археологических исследований в пределах сооружений, была выявлена керамика, датируемая VIII-XII вв [4].

От городища Агашаяк путь далее следовал к городищу Карамерген, которое находилось в 40 км (Фото 17, географические координаты $46^{\circ} 15^{\prime} 17^{\prime \prime} \mathrm{N}$, $\left.75^{\circ} 37^{\prime} 33^{\prime \prime} \mathrm{E}\right)$. По своей форме городище имеет форму прямоугольника размером 115 х 120 м, углы которого ориентированы по сторонам света. Сохраненные глинобитные стены, достигающие высоты до 3 м, ныне оплыли и имеют валоподобную форму. По четырем углам выступают округлые башни высотой в 4,5 м. Поселение снабжалось водой по каналу от одного из притоков реки Ортасу, проходящего в 1 км от юго-восточной стороны городища. На территории городища археологами найдена керамика, датируемая VIII-XIII вв., а также медный шлак, свидетельствующий о развитии меднолитейного производства на его территории [4]. В тюрское время городище Карамерген вероятно представляло собой площадку размером 115х120 метров, огражденной земляным валом. После прихода огузов оно было перестроено в городищекрепость. На ранее высыпанных тюрками валах, огузами были возведены оборонительные глинобитные стены с башнями, для защиты от нападений враждующих кимакских и карлукских племен. В 2014 году городище Карамерген вошло в список Всемирного наследия ЮНЕСКО в Казахстане.

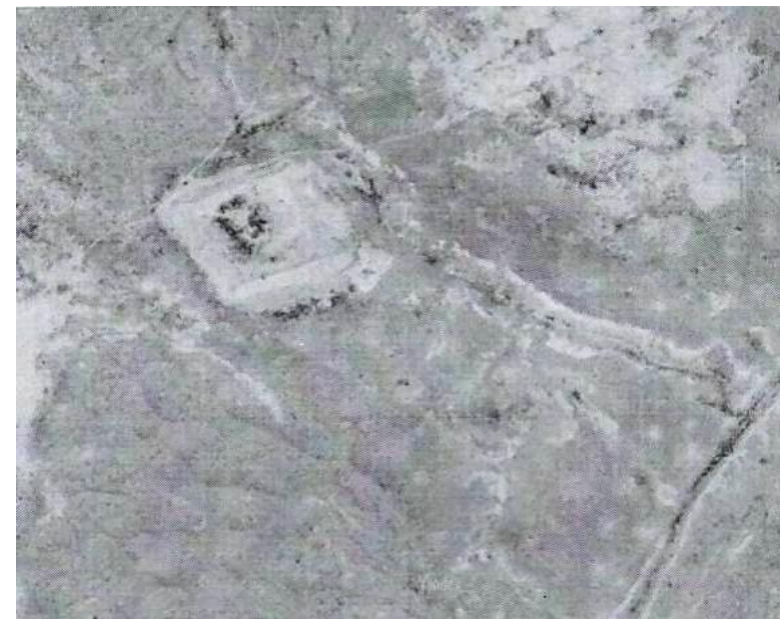

Фото 17. Древнее городище Карамерген.

Многими археологами, изучавшими древнюю долину реки Или, городище Карамерген считалось последним местом проживания местных земледельцев и остановок караванов на данном ответлении Шелкового пути. Однако, при просмотре спутниковых снимков, мною в прибрежной зоне южного берега озера Балхаш, с левой стороны русла Ортасу, в 26 км к северовостоку от городища Карамерген, было выявлено новое неизвестное ранее городище № 4 (Фото 18, географические координаты $46^{\circ} 26^{\prime} 35^{\prime \prime} \mathrm{N}$, 75²6'38"Е). Очевидно, оно служило следуюшим пунктом остановки для проходящих караванов описываемого ответвления Шелкового пути.

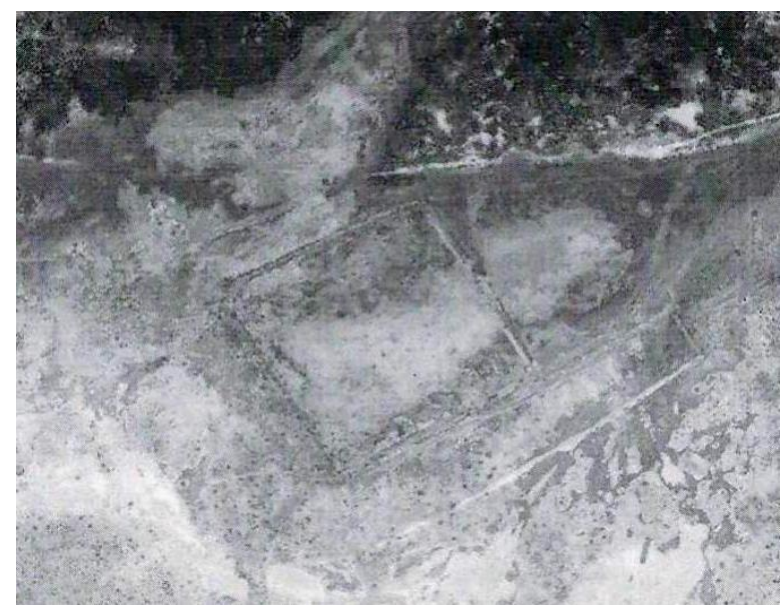

Фото 18. Неизвестное городище № 4 (прототип древнего городища Горгуз).

В плане это городище представляло собой прямоугольник размером 200х200 метров, ориентированный углами по сторонам света.
Территория городища, была, вероятно, окруженна саманной стеной, превратившаяся со временем при поднятии воды в озере Балхаш, в оплывший вал. 
Внутри его отмечаются остатки разрушенных и оплывших стен внутренних помещений, предназначавшихся для постоянного проживания и хранения товаров. Снаружи городище с северозападной, северо-восточной и юго-востоной стороны, еще было окружено невысокой стеной, также оплывшей на сегоднягний день, размером $360 \times 360$ метров. Вдоль северо-западной и юговосточной части стен по всей длине, отмечаются остатки стен помещений по 12 единиц с каждой стороны, служившие повидимому для временного проживания караванщиков и обслуживающего персонала, а также как складские помещения для товаров и животных. В северо-западной и северовосточной части от выявленного неизвестного городища в прибрежной береговой зоне, среди зарослей камыша по спутниковым снимкам, отмечается серия квадратоподобных площадок, возможно являющихся остатками еще ряда небольших временных стояночных поселений. Выявленное неизвестное городище, могло соответствовать огузкому городу-крепости Горгуз, описываемым арабским географом Мухамедом аль-Идриси в X-XI ст. [5], которое являлось центром огузких племен проживаюших на территории древней дельты реки Или и очевидно ставкой их вождя.

Далее путь следовал вдоль русла Ортасу через перешеек, разделяющий озеро Балхаш на две части, в долину реки Токрау, где проживали кимакские племена. При просмотре спутниковых снимков, мною было выявлено еще одно неизвестное полуразрушенное городище № 5, построенное очевидно кимаками (Фото 19, географические координаты $\left.46^{\circ} 45^{\prime} 53^{\prime \prime} \mathrm{N}, \quad 75^{\circ} 28^{\prime} 42^{\prime \prime} \mathrm{E}\right)$. Оно находится в 40 км на северо-восток от описанного выше неизвестного городища на южном берегу озера Балхаш.

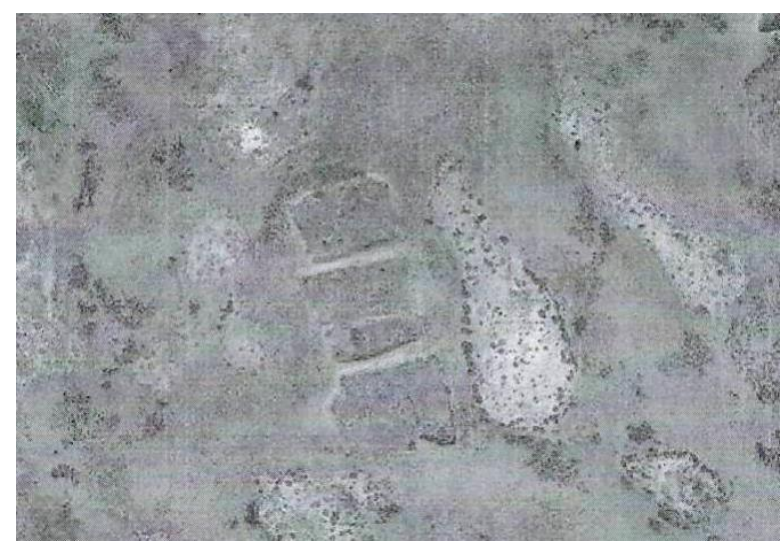

Фото 19. Неизвестное городище № 5.

Его сооружение отличается от городищ, построенных тюрками и огузами в древней дельте реки Или. Центральная часть городища представляет собой четырёхугольный торткуль размером 110х110 метров, окруженный оплывшим валом и ориентированный под небольшими углами по сторонам света. Северо-западная и юговосточная стороны валов имеют большую ширину, а северо-восточная и юго-западная небольшую. Это, по всей видимости, было связано с увеличением уровня воды в руслах реки Токрау, при наводнениях, что приводило к размыванию этих валов. Внутри городища, в южной стороне, просматривается остаток стены прямоугольного сооружения. С северо-западной и юго-восточной стороны городища, расположены еще две четырехугольные площадки, размером 100х60 и 110x100 метров, окруженные с наружи небольшими оплывшими валами, которые также были размытые потоками воды реки Токрау. Данные площадки, очевидно, служили для временных стоянок животных проходящих местных и транзитных торговых караванов. Вокруг описываемого городища, в радиусе от 1 до 3 км, еще находится большое количество квадратов от саманных жилищ, в которых проживали кимаки, занимающие выращиванием животных и сбытом их продукции торговцам караванов.

От этого городища, местные торговые караваны дальше шли в районы Центрального и Восточного Казахстана, которые были богатыми разнообразными ископаемыми металлами и драгоценными камнями, а также скотом, шерстью и кожами, в которых нуждались многие крупные города Южного Казахстана и Семиречья. Транзитные торговые караваны следовали вдоль реки Токрау через горные массивы Центрального Казахстана, стыкуясь затем с караванными дорогами, проходящими через территорию Северного Казахстана.

В древнюю долину реки Или караваны попадали еще другим путем, который шел от городища Тальхиз через торткуль Жаксылык, находящийся на трассе к городищу Чингильды. От торткуля Жаксылык, дорога дальше следовала вдоль левого побережья реки Или в район впадения реки Курты, где на левом берегу реки Курты на восточной окраине современного поселка Актогай, находилось выявлено мною по спутниковым снимкам, неизвестное городище № 6 (Фото 20, географические координаты $44^{\circ} 17^{\prime} 08^{\prime \prime} \mathrm{N}$, $\left.76^{\circ} 41^{\prime} 43^{\prime \prime} \mathrm{E}\right)$. 


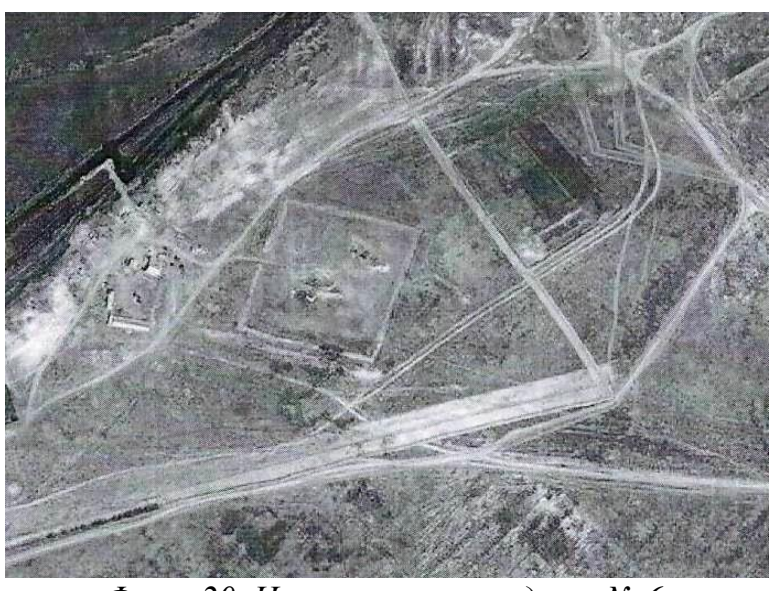

Фото 20. Неизвестное городище № 6.

Неизвестное городище, расположенное возле поселка Актогай и по своей форме напоминает городища, находящиеся вдоль выше описанного ответвления Шелкового пути от поселка Акший до городища Бояулы. В плане это четырехугольная площадка размером 140x150 м, ориентированная углами по сторонам света и окруженная оплывшим валом. Въезд в городище в середине вала с северозападной стороны. Так как расстояние между торткулем Жаксылык и неизвестным городищем равнялось 80 километрам, то для временной остановки проходящих караванов использовались стационарные жилища-зимовки, где проживали местные земледельцы и скотоводы. Большая часть этих стоянок распологалась в интервале около 40 км между городищами, возле небольших русел мелких рек, впадавших в реку Или (географические координаты одноого из них $44^{\circ} 01^{\prime} 03^{\prime \prime} \mathrm{N}$, 76 53'38"Е), вдоль которых по спутниковым снимкам просматриваются караванные дороги и тропы. Далее путь этого ответвления Шелкового пути от неизвестного городища, следовал по левому берегу долины реки Или, соединяясь с маршрутом первого ответвления, шедшим к городищам Бояулы, Актам, Агашаяк, Карамерген и неизвестному (Горгуз) на берегу озера Балхаш.

Еще древняя долина реки Или, большую роль сыграла в развитии городской культуры юговосточного Семиречья. $B$ IX-XII веках, здесь проходила трасса второго Великого Шелкового пути, следовавшего от оазиса Хами через Джунгарские ворота к городищу Тальхиз. На его пути находились два крупных города, такие как Икиогуз (Эквиус) и Каялык (Койлак), в котором располагалась ставка карлуков. Они в юговосточном Семиречье являлись центрами ремесла и торговли. Своих земледельческих и животноводческих продуктов, соли, а также производственных материалов для изготовления орудий труда и других изделий, местным торговцам и мастерам-ремесникам не хватало. Поэтому им требовалось налаживать торговые отношения с городищами древней дельты реки Или и районами Северного Прибалхашья, используя трассу описываемого ответвления Шелкового пути. Судя по спутниковым снимкам, их караваны в районы городищ древней дельты реки Или, выходили несколькими путями. Большая часть караванных дорог и троп проходила через песчаную пустыню Сарыесик-Атырау, где находилось много жилищ-зимовок скотоводов, которые использовались караванщиками для временной остановки. Другие караваны следовали вдоль рек Каратал, Лепсы и Аксу к южному побережью озера Балхаш, двигаясь дальше вдоль берега озера Балхаш к городищу Карамерген, выходя потом на трассу ответвления Шелкового пути. Эти караванные дороги и тропы, сокращали время движения караванов в районы Северного Прибалхашья.

C XII века на территории Средней Азии происходило масштабное глобальное потепление, приведшее к широкомасштабному таянию ледников в горах Джунгарского Алатау и ТяньШаня [2]. В последствии, эти климатические процессы в XIII веке, вызвали увеличение воды в Джунгарской впадине и в реках, впадающих в Балхаш-Алакольскую впадину, что привело к поднятию уровня воды на несколько десятков метров в озерах Балхаш, Алаколь и Сасыкколь, которые впоследствии воссоединились и образовали единый Балхаш-Алакольский водоем. О том, что эта территория в те времена затоплялась, говорят ряд фактов, выявленные мною при проведении глубинных геолого-съемочных работ в районе известного городища Карамерген. Так на отдельных склонах песчаных барханов, на высотах до 10 метров, мною были обнаружены глыбы каменных пород, размером от первых до 2-3 метров. Такими породами слагались скалистые и каменные берега северной части берега оз. Балхаш и его островов, большая часть которых при затомлении, оказалась под водой. Тогда, в зимние периоды, Балхаш-Алакольский водоем покрывался льдами толщиной до 1 м, которые захватывали и обволакивали все скальные выходы берегов и вновь образованных островов с валунами и глыбами. С наступлением весеннего тепла, уровень воды в Балхаш-Алакольском водоеме повышаться и льдины с захваченными валунами и глыбами скальных пород, под действием северо-восточных ветров, а также течений, начинали перемещаться по поверхности водоема в сторону затопленного Южного Прибалхашья. Потом они зависали на 
барханах и при дальнейшем потеплении, начинали таять, оставляя на них, захваченные валуны и глыбы скальных пород.

При детальном осмотре городища Карамерген, мною было еще отмечено, что его стены имеют размытую и оплывшую округлую форму. С наружной стороны, они пологие с небольшими террасами и остатками мелких ракушек на них, какие бывают на берегах речек и озер, а с внутренней - более ровные без террас, что подтверждает их длительное затопление. Однако казахские археологи считают, что городище Карамерген и другие близлежащие городища в джревней долине реки Или, были разрушены в ходе монгольского нашествия в XIII в., хотя особых следов разрушений человеческими руками на нем и на других городищах, я не видел. Поэтому считаю, это мнение археологов неверное, о чем свидетельствуют приведенные мною факты. Южная береговая линия этого водоема, тогда проходила севернее поселка Баканас вдоль южной части пустынь Таукум и Сарыесик-Атырау, затопив тем самым всю плодородную часть древней дельты реки Или с её земледельческими и скотоводческими поселениями, а также городища Бояулы, Актам, Агашаяк, Карамерген и неизвестное (Горгуз), находящееся на южном берегу озера Балхаш. Это привело проживающие население огузких и карлукских племен, покинуть территорию древней дельты реки Или и пустыни Сарыесик-Атырау, перекочевав в другие доступные для обитания места. Поэтому завоёвывать затопленную территорию древней дельты реки Или с её городищами монгольским войскам не было смысла. Они на самом деле, двигались вдоль предгорья Джунгарского Алатау по караванным дорогам Шелкового пути, разрушая находящиеся вдоль него городища и земледельческие поселения.

Еще одним важным фактором, подтверждающим поднятие уровня воды в БалхашАлакольской впадине, явилось действие стекающих водных потоков из Джунгарской впадины через Джунгарские ворота, колорые размывали и углубляли уже сформированную ранее в северной части Балхаш-Алакольской впадины полуокруглую месяцеподобную вымоину. О силе стекающих потоков воды, происходивших в те времена, хорошо видно в районе дельтового перешейка, разделяющего в те времена озеро Балхаш на две части, где в результате этих течений была размыта северная её часть и образован современный Узынаральский пролив с полуостровом Сарыесек. В дальнейшем, данный пролив, перекрыл переход в древнюю дельту реки Или со стороны Северного Прибалхашья, нарушив торговые связи Южного Прибалхашья с районами Центрального и Северного Казахстана, остановив движения караванов ответвления Великого Шелкового пути.

Со временем, уровень воды в БалхашАлакольском водоеме начал падать, разделившись на современные озера Балхаш, Алаколь и
Сасыкколь. Река Или, в связи с повышенной наносностью, изменила свое направление и начала протекать по западному рукаву старой дельты, образуя новую дельту с многочисленными разветвлениями рукавов, впадающих в югозападную часть озера Балхаш, а обезвоженная территория древней дельты реки Или превратилась в пустыню с песчаными дюнами, барханами и сухими руслами-баканасами, непригодной для проживания населения, ведения земледелия, кочевого и полукочевого скотоводства.

Заключение. Таким образом, мы видим, что на территории древней дельты реки Или с середины 2-го тысячелетия до нашей эры и по XIII в. н.э. развивалось не только скотоводческая кочевая культура, но и оседло-земледельческая. В период IX-X вв на территориях Семиречья и Южного Казахстана начала развиваться городская культура торговых центров вдоль трасс Великого Шелкового пути, которым своих сельскохозяйственных и животноводческих продуктов, выращенных вокруг городищ и поселений, не хватало. Это привело к повышению спроса на продукты животноводства и земледельческих культур, необходимых для питания проживающего городского населения, людей обслуживающих караваны и караванных животных. В связи с этим, регион древней реки Или становится в Семеречье и Южном Казахстане центром орошаемого земледелия и животноводства, а также добычи соли. Вначале для постоянного оседлого проживания, местным населением в сакско-усуньское время строились поселения из жилищ-землянок и полуземлянок, а в тюрско-огузкое время использовались юрты и глинисто-саманные жилища, которые в дальнейшем группировались в небольшые укрепленные поселения-городища, становлясь в дальнейшем центрами земледелия и животноводства. Для вывоза выращенных в древней долине реки Или земледельчиских и животноводческих продуктов, а также добываемой соли, от городищ и торговых центров, расположенных вдоль трассы Великого Шелкового пути, были проложены караванные дороги, часть из которых потом были вовлечены в систему международных торговых связей Великого Шелкового пути.

Одна из веток Шелкового пути проходила вдоль древней долины реки Или через ТокрауИлийский перешеек, разделяющий озеро Балхаш, в районы Западного, Центрального и Восточного Казахстана, богатых разнообразными ископаемыми металлами и сельхозтоварами, в которых нуждались крупные города и городища Южного Казахстана. Для временных остановок проходящих караванов тюрками и огузами строились городища-крепости, укрепленные стенами или земляными валами. При просмотре спутниковых снимков, автором было выявлено и описано ряд новых неизвестных городищкрепостей и поселений-торткулей, расположенных вдоль движения трассы описываемого ответвления Шелкового пути, а так же неизвестное городище на 
южном берегу озера Балхаш, являющимся очевидно прототипом огузкого города-крепости Горгуз. На выявленных автором сакско-усуньских поселениях из жилищ-землянок и тюрко-огузких неизвестных городищах, казахским археологам необходимо провести комплекс исследовательских работ по их изучению, что будет способствовать новым открытиям в казахской археологии и обеспечит их сохранность.

Приведено описание движения основных марирутов торговых караванов вдоль реки Курть и древней дельты реки Или, от городищ Семиречья и торговых центров Южного Казахстана, расположенных на трассах Великого Шелкового пути. Следовательно, они оказывали существенное воздействие на культурную и хозяйственную жизнь проживающих племен в древней дельте реки Или и на её прилегающих территориях.

Однако, в результате климатических катаклизмов проходивших в XII-XIII веках в районах Средней Азии и приведших к поднятию воды в пределах Балхаш-Алакольской впадины, что явилось одной из причин остановки развития оседло-земледельческой культуры в древней дельте реки Или, переселению проживающего населения в другие места и закрытию торговых караванных дорог ответвления Великого Шелкового пути.

\section{Список литературы:}

1. Агаджанов С.Г. Очерки истории огузов и туркмен Средней Азии IX-XIII вв. [Электронный pecypc] - Режим доступа: http://book.kyrgyz.ru/ocherki-istorii-oguzov-i-

turkmen-sredney-azii-ixhiii-vv/(дата обращения: 05.11.2019).

1.2. Стасив И.В. О происхождении озера Балхаш и Балхаш-Алакольской впадины.
//Евразийский Союз Ученых (ЕСУ): научный журнал № 4(49)/2018, 5 часть, стр.5-10. [Электронный ресурс] - Режим доступа: https://euroasia-science.ru/wp-

content/uploads/2018/05/Euroasia_апрель_журнал_5 _ча-22.pdf (дата обращения: 05.11.2019).

3. К.А. Акишев, Г.А. Кушаев. Древняя культура саков и усуней долины реки Или. АлмаАта: АН КазССР, 1963.3320с. [Электронный pecypc] - Режим доступа: http://kronk.spb.ru/library/akishev-kushaev-1963.htm (дата обращения: 05.11.2019).

4. “Летопись ЖЕТЫСУ” - Алматы: “Асыл сөз” баспасы, 2012. - 328 стр. https://ehistory.kz/media/upload/56/2013/08/26/2fd3883ba246 913f428ffdff4ac03888.pdf (дата обращения: 05.11.2019).

5. Расселение огузских племен в X в. [Электронный pecypc] - Режим доступа: https://taryhturkmen.blogspot.com/2014/12/x.html (дата обращения: 07.11.2019).

6. Направления и трассы Великого Шелкового пути. Интернет проект Qazaqstan tarihy. [Электронный ресурс] - Режим доступа: https://ehistory.kz/ru/contents/view/318 (дата обращения: 06.11.2019).

7. Ганиева А.С. Вклад К.А.Акишева в изучение средневековой городской культуры Казахстана. Источник:http://nblib.library.kz/elib/library.kz/journ al/Ganieva......2010...pdf (дата обращения: 07.11.2019).

8. ГОРОДА В СТЕПИ: Археологические исследования $\quad$... _ $\quad$ - Texts.News https://texts.news/istoriya-kazahstana_1441/gorodastepi-50343.html (дата обращения: 07.11.2019). 